\title{
Kwalitatieve ranglijsten van medische opleidingen zijn onbruikbaar
}

\author{
H.J. Huisjes
}

Is een kwalitatieve ranglijst van medische opleidingen op betrouwbare wijze op te stellen? Dat lijkt mij om twee redenen niet mogelijk. Ten eerste vanwege de moeilijkheid om te bepalen welke kwaliteiten meer of minder relevant zijn voor de beoordeling en ten tweede vanwege de rekenkundige problemen die zich voordoen bij het opstellen van een ranglijst.

Wat het eerste probleem betreft, momenteel zijn er 4 beoordelingen van artsopleidingen courant. In het verslag van de Onderwijsvisitatie Geneeskunde wordt een groot aantal variabelen op een 4puntsschaal beoordeeld. ${ }^{1}$ In het document Kennis in kaart, uitgebracht door het ministerie van Onderwijs, Cultuur en Wetenschappen, worden de percentages "onvoldoende", "voldoende" en "excellent" van de beoordeling door de visitatiecommissie weergegeven. ${ }^{2}$ Deze beide documenten pretenderen niet een rangorde van opleidingen te geven. In de Keuzegids hoger onderwijs voor 2005-2006 (www.keuzegids.org/) en het themanummer van Elsevier over studeren van november 2005 berust de rangorde van opleidingen op enquetes onder studenten en hoogleraren. De door hen toegekende scores op een aantal opleidingsaspecten worden ongewogen gemiddeld om tot een eindscore per opleiding te komen. Deze methode levert zeker belangwekkende informatie op, maar doet geen recht aan de verschillen in gewicht tussen de beoordeelde aspecten.

Het tweede probleem betreft de waarderingsschaal waarop de scores per aspect kunnen worden afgezet. In verreweg de meeste gevallen is dat bij de beoordeling van een opleiding geen intervalschaal, zoals gebruikt voor lengte en gewicht, maar een ordinale schaal (zoals gebruikt voor aardbevingen en windkracht), waarbij eenzelfde kwantitatief verschil op verschillende plaatsen in de schaal een andere betekenis kan hebben. Zo'n schaal is niet geschikt voor de gangbare rekenkundige bewerkingen. ${ }^{3}$

Overigens heeft de invoering van het visitatiestelsel er wel toe geleid dat de kwalitatieve verschillen tussen de opleidingen veel kleiner zijn geworden. Het ontbreken van zinvolle en betrouwbare ranglijsten is dan ook niet zo'n gemis. Aspirant-studenten, op zoek naar de voor hen geschiktste opleiding, zullen veel meer hebben aan een korte omschrijving van wat elke opleiding als haar typische kenmerken en sterke punten beschouwt: wetenschap of klinische praktijk, individuele patiëntenzorg of maatschappelijke gezondheidszorg, een hoog studierendement of veel en langdurige buitenlandse stages. Ter wille van de objectiviteit zou een dergelijke omschrijving wellicht niet door de opleidingen zelf, maar door een ter zake kundige commissie moeten worden opgesteld. De omschrijvingen per opleiding die in het visitatierapport worden gegeven zijn niet geschikt, omdat ze te technisch en te lang zijn. De andere beoordelingen garanderen niet de noodzakelijke deskundigheid en diepgang. Naar mijn mening zal de nieuwe accreditatieprocedure, die de visitatie gaat vervangen, evenmin in deze behoefte voorzien. 


\section{Literatuur}

1. Onderwijsvisitatie Geneeskunde. Utrecht: Stichting Quality Assurance Netherlands Universities (QANU); 2004.

2. Ministerie van Onderwijs, Cultuur en Wetenschap (OCW). Kennis in kaart. Zoetermeer: Speed Print; 2005.

3. Meer J van der. Moeilijke keuzen aan het ziekbed; reken niet op de besliskunde. Ned Tijdschr Geneeskd 1988;132:336-7.

\section{De auteur:}

Prof. dr. H.J. Huisjes is arts.

Correspondentieadres:

Prof. dr. H.J. Huisjes, Kalkwijk 177, 9603 TC Hoogezand.

Belangenconflict: geen gemeld.

Financiële ondersteuning: geen gemeld.

\section{Summary}

Saying that a qualitative ranking of medical schools would be helpful implies that it is feasible. There are two reasons why this may not be the case. Firstly, any medical school can be characterised by many aspects of varying quality and importance, not necessarily "good" or "bad", resulting in an arbitrary assessment of overall quality. Secondly, evaluation of an aspect results in a score on an ordinal scale, which is not suitable for current arithmetic operations. Since the introduction of the visitation system, the qualitative differences between schools have decreased. Therefore, an objective description of each of the medical schools, including its special characteristics, would be more useful for the aspirant student than ranking. (Huisjes HJ. Qualitative ranking of medical curricula is useless. Dutch Journal of Medical Education 2006;25(5):237-238.) 